\title{
Low Level Jet Wind Shear in the Sahel
}

\section{Madougou Saïdou, ${ }^{1, a}$, Saïd Frederique ${ }^{2, b}$, Campistron Bernard ${ }^{3, c}$ and Cheikh Fadel Kebe ${ }^{4, d}$}

\author{
${ }^{1}$ Ecole Normale Supérieure / Université Abdou Moumouni de Niamey; BP 10963 - Niamey, Niger \\ 2,3 Université de Toulouse; Laboratoire d'Aérologie, CNRS UMR 5560, France \\ ${ }^{4}$ Université Cheikh Anta Diop de Dakar, Sénégal \\ anassara01@yahoo.fr (Corresponding author) \\ bfrederique.said@aero.obs-mip.fr; ${ }^{\mathrm{b}}$ bernard.campistron@aero.obs-mip.fr; ${ }^{\mathrm{d}} \mathrm{cmkebe@gmail.com}$
}

Keywords: Low level jet, Wind shear, Wind shear direction, Aircraft.

\begin{abstract}
In the Sahel, a vertical wind shear appears in the dry and in the wet seasons. In Niamey, Niger, during the dry season, the period of strong shears is clearly linked to the Nocturnal Low Level Jet (LLJ) since it occurs in a narrow time period around $06 \mathrm{H} 00 \mathrm{UTC}$ at $60 \%$ of the cases reach shears which require an alert to the pilots (higher than $4 \mathrm{~ms}^{-1}$ per $100 \mathrm{~m}$ ). The majority of cases occur during the night with a wind shear direction between 90 and $150^{\circ}$ per $100 \mathrm{~m}$, which is shown that it is dangerous for aircraft. In Bamako, Mali, high wind shears represent (higher than 4 $\mathrm{ms}^{-1}$ per $100 \mathrm{~m}$ ) only $16-22 \%$ of the cases and can occur at any time of the day. There are, however, $8 \%$ of the cases, the whole day long, when the wind shear can reach more than $6 \mathrm{~ms}^{-1}$ per $100 \mathrm{~m}$. Most of the wind shear directions are also between 0 and $90^{\circ}$ per $100 \mathrm{~m}$ during the night. This is why the Agency for the safety of aircraft navigation in Africa and Madagascar (ASECNA) has put in 2004 at Bamako airport an UHF wind profiler radar for monitoring nocturnal strong Low Level Jet wind shear which occur regularly in this airport.
\end{abstract}

\section{Introduction}

In the Sahelian band, the year is characterized by for four seasons: the dry season, the pre-monsoon, the monsoon and the post-monsoon. These seasons are linked to the northward migration of the Intertropical Convergence Zone (ITCZ) with the seasonal motion of the sun. South of the Sahara desert, there is a dry season in winter with dry, warm easterly to northerly winds (the Harmattan) associated with high pressure over the Sahara whereas, during summer, the monsoon winds blow from the south-west in the low layers, carrying cooler and moister air associated with rainfall.

The migration of the ITCZ induces a meridional variability in rainfall. The diurnal cycle of the wind is marked and the vertical profiles do not follow the usual logarithmic profile close to the ground due to the existence of a strong nocturnal low level jet. The regularity of this diurnal cycle and the repetitivity of the wind structure are others factors which define the characteristics of the seasons. The Sahel is an area where the nocturnal low level jet occurs regularly. The strength, level and direction of these LLJs vary during the daytime [1].

Wind shears occurring near the ground can be due to low level jets, downbursts of thunderstorms or the presence of large obstacles on the ground. The wind shear between two levels is the difference between the two horizontal wind vectors. It is thus defined both in magnitude and in direction. Wind shears are known to disturb air properties around airplanes by generating sudden disturbance of the relative wind speed or by producing turbulence. They therefore constitute major risks during take-off and landing of the aircraft [2]. They are known to have been directly or indirectly responsible for many aircraft disasters between 1964 and 1986 in USA and some parts of the world. The aim of this paper is to present the nocturnal low level jet wind shear in the Sahel, which occurs near the ground and constitutes major risks during the take-off and landing of aircraft. 


\section{Materials and Methods}

Our data were obtained from two wind profiler radars installed at Bamako in 2005 and at Niamey in 2006 and cover two eight-months of observations collected during the dry and wet seasons of the African Monsoon Multidisciplinary Analysis (AMMA) field campaign in West Africa. These wind profiler radars provided continuously vertical profiles of the wind with a good time resolution associated with the documentation of the vertical profile of the wind.

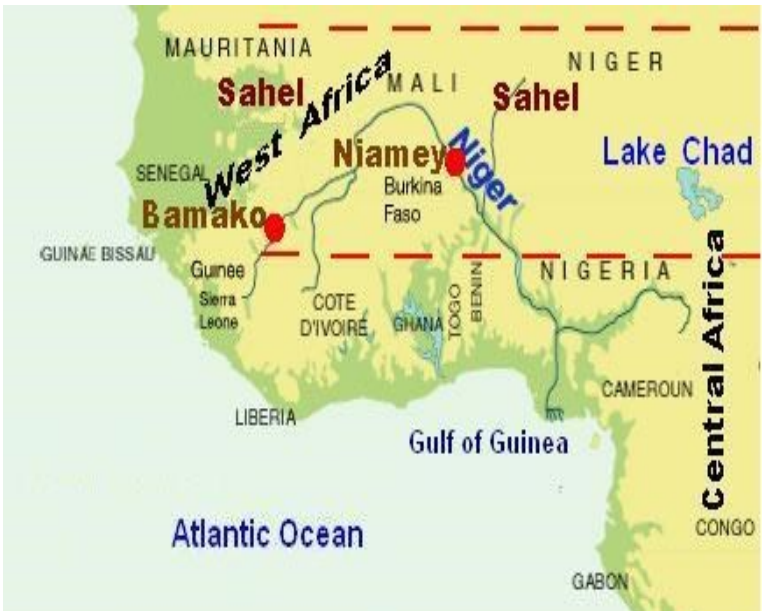

Figure 1 AMMA field observation extends from the edge of Atlantic Ocean in West Africa to the coast of Central Africa, including Lake Chad and the Gulf of Guinea. The measurements presented here were acquired in Niamey and Bamako (red dots) which are located in the Sahel band (red dashed lines)

Bamako and Niamey are situated in the Sahelian band and are roughly $100 \mathrm{~km}$ apart in latitude. Niamey is at $13^{\circ} 29^{\prime} \mathrm{N}, 2^{\circ} 10^{\prime} \mathrm{E}$ and $227 \mathrm{~m}$ asl in south west Niger and Bamako at $12^{\circ} 32^{\prime} \mathrm{N}, 7^{\circ} 57^{\prime} \mathrm{W}$ and at $380 \mathrm{~m}$ asl in south west Mali (Figure 1). The radar installed at Bamako is an UHF PCL 1300 (Figure 2a) to monitor the nocturnal strong low-level wind shears that regularly compromise the safety of aircraft on landing and take-off. This radar was operated during 2005 from March $4^{\text {th }}$ until December $29^{\text {th }}$ without interruption except for an inactive period from May to June due to technical problems. This radar suffered from technical problems after December 2005, even after repair, the data were no longer recorded.

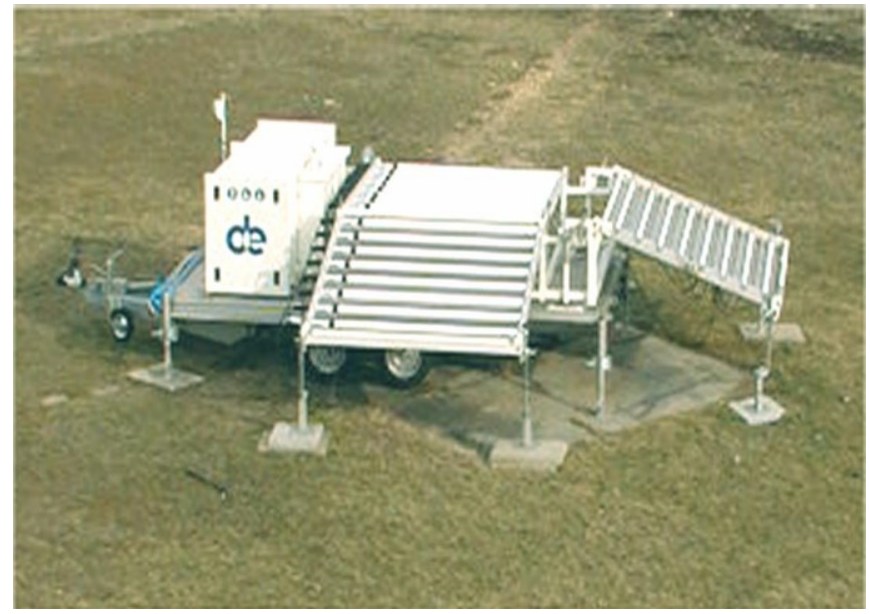

Figure 2a Bamako UHF PCL 1300 Wind profiler radar

The second radar (Figure 2b) was installed at Niamey airport in March 2006 during the AMMA EOP in the framework of the US ARM program (Atmospheric Radiation Measurements) and provided data from April $4^{\text {th }}, 2006$ to January $6^{\text {th }}, 2007$, except for an inactive period from June $17^{\text {th }}$ to July $2^{\text {nd }}$. 


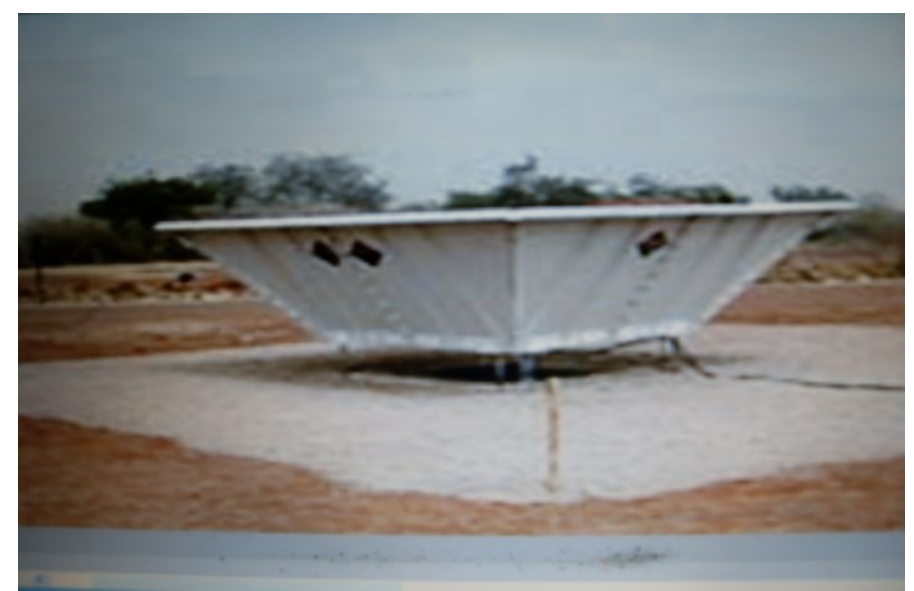

Figure 2b Niamey UHF Wind profiler Doppler radar

UHF radar measures wind vertical profiles and backscattered signal strength between about 0.1 and 3-5 km depending on the conditions of the atmosphere. It operates by transmitting electromagnetic energy into the atmosphere and measuring the strength and frequency of the backscattered energy and can work in clear air or during precipitation events. The radars provide vertical profiles of the three components of the mean wind, turbulence parameters, Atmospheric Boundary Layer (ABL) top $\mathrm{Zi}$ and qualitative information on precipitation and air humidity. In clear air, the atmospheric signal is due to the backscattering by spatial irregularities of the air refractivity index at the scale of half the radar wavelength when the source of the fluctuations comes from turbulent mixing which follows the behavior of the Kolmogorov inertial subrange. Air refractivity depends on temperature and humidity, the latter dominating in the lower atmosphere. The observation made by those two Doppler profilers was based on a repetitive sequence cycling over the five beams, of 5.23-min duration in Niamey and 2.5-min in Bamako, and comprising a high and low collection mode. Vertical profiles of the wind are deduced from the Doppler spectra obtained at each level gate of the five radial directions for each cycle of measurements. The three wind components are deduced from the mean Doppler radial velocity measured on all beams with the assumption of local horizontal field homogeneity. Only the low mode will be used here. The difficulty of operating with profiler radar used in clear air is the fact that the meteorological echoes (produced by the wind) are very faint relative to the noise. So the data processing is rather complex.

\section{Results and Discussion}

Nocturnal Low-Level Jet Description: Figure 3 shows the monthly vertical profiles of wind speed observed at Bamako and Niamey at $00 \mathrm{H} 00,06 \mathrm{H} 00,12 \mathrm{H} 00,18 \mathrm{H} 00$ and $21 \mathrm{H} 00 \mathrm{UTC}$ during the four characteristic periods: April at Bamako and May at Niamey for the pre-monsoon period, August, October and December for the monsoon, post-monsoon and dry season respectively at both sites. These figures show an increase of wind speed between 200 and $800 \mathrm{~m}$ with a well marked maximum between $00 \mathrm{H} 00$ and $06 \mathrm{H} 00 \mathrm{UTC}$, especially during the dry or pre-monsoon periods. This Nocturnal Low Level Jet is much less marked during the monsoon period. In general, the jet is not yet formed at $18 \mathrm{H} 00 \mathrm{UTC}$ and sometimes not even at $21 \mathrm{H} 00 \mathrm{UTC}$, as was shown by Malcher and Kraus [3]. The maximum jet (wind speed of about $14 \mathrm{~ms}^{-1}$ ) occurs during the dry season at $06 \mathrm{H} 00$ UTC. The maximum of the jet is not located at a constant level in the different figures: the jet peak corresponds to the top of the stable nocturnal layer [2] and its evolution is linked to the evolution of the stability conditions. In our data set, most of the time the jet level increases between $00 \mathrm{H} 00$ and 06H00 UTC which is in agreement with the stability evolution. Despite the variability of profiles, the repetition of the structure of the jet in the low troposphere has enabled a composite day to be developed, corresponding to the average of profiles every half-hour for each month. The height-time cross sections in Figure 4 show the composite days of the horizontal wind in August and December. 


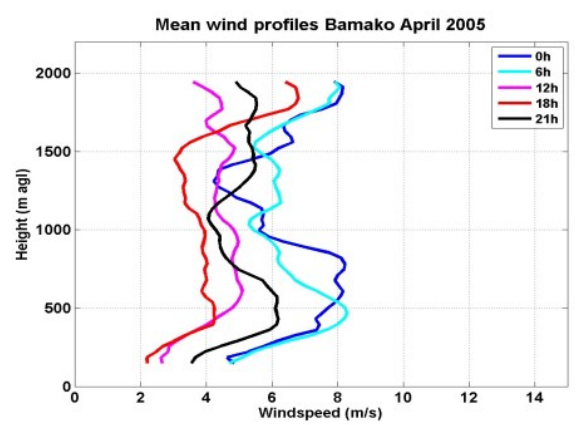

(i-a) Pre-monsoon at Bamako

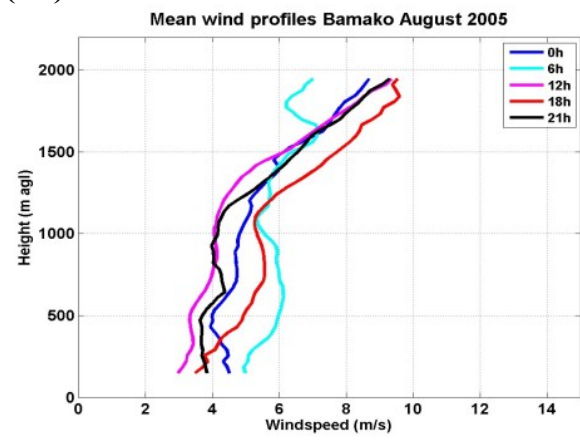

(ii-a) Monsoon at Bamako

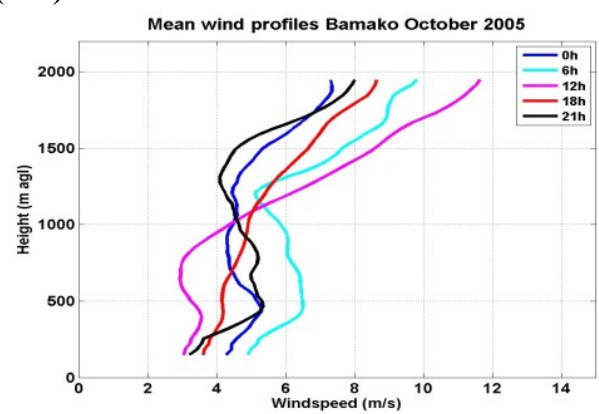

(iii-a) Post-monsoon at Bamako

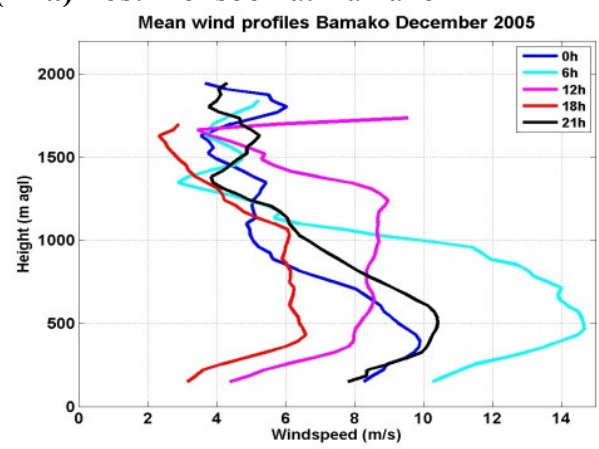

(iv-a) Dry season at Bamako

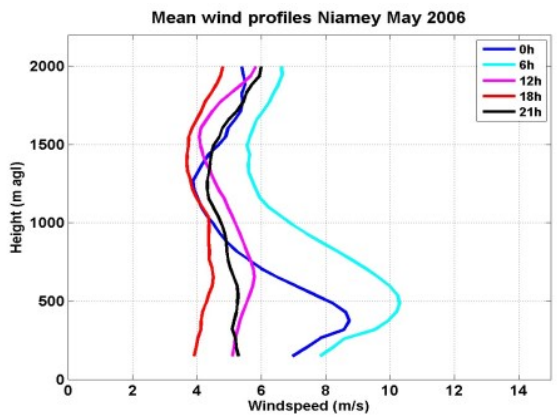

(i-b) Pre-monsoon at Niamey

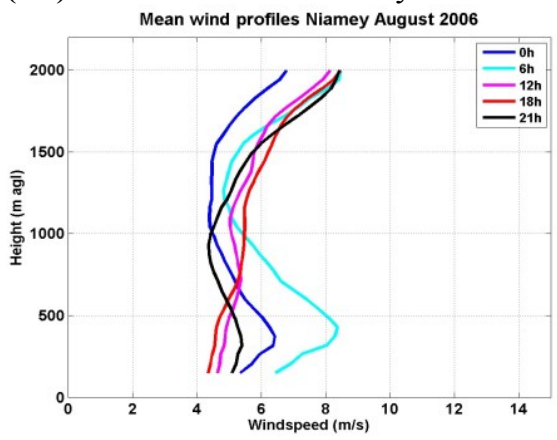

(ii-b) Monsoon at Niamey

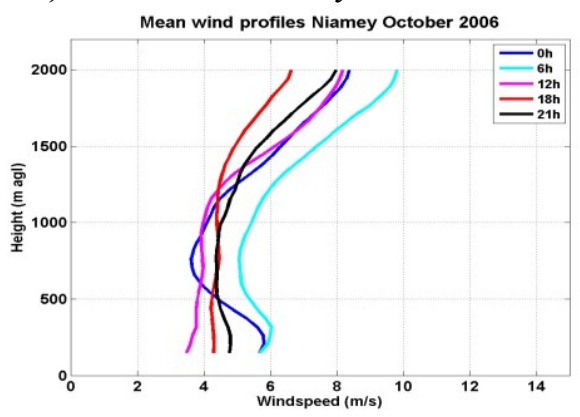

(iii-b) Post-monsoon at Niamey

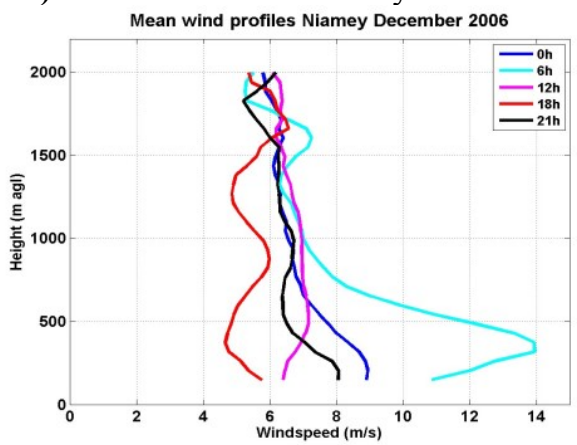

(iv-b) Dry season at Niamey

Figure 3 Vertical profiles of wind speed observed at night $(00 \mathrm{H00} ; 06 \mathrm{H00} ; 18 \mathrm{H00}$ and $21 \mathrm{H00} \mathrm{UTC})$, at Bamako in 2005 and (b) Niamey in 2006 (i) Pre-monsoon, (ii) Monsoon, (iii) Post-monsoon, (iv) Dry season.

During the rainy season (Figures $4 \mathrm{a}$ and $4 \mathrm{~b}$ ), the African Easterly Jet (AEJ) is positioned at the latitudes of Niamey and Bamako, and blows steadily from east to west, spreading from 3 to $5.5 \mathrm{~km}$ agl and peaking around $15 \mathrm{~ms}^{-1}$ at both locations, as shown by Kalapureddy et. al. [4]. The Inter Tropical Discontinuity (ITD) is located between 15 and $20^{\circ}$ north, and the low layers are affected by a weak monsoon flow (less than $3 \mathrm{~ms}^{-1}$ ), blowing from the south-west. 
The interface between the monsoon and the Harmattan is roughly at $1000 \mathrm{~m}$. A cell of stronger wind appears at night: it corresponds to the LLJ which brings moisture from lower latitudes into a thin layer close to the surface as described in Lothon et. al. [5]. It only reaches 5-7 $\mathrm{ms}^{-1}$ on average during the rainy season. This jet is much more marked during the dry season (Figure $4 \mathrm{c}$ and $4 \mathrm{~d}$ ) when it reaches $13 \mathrm{~ms}^{-1}$. Its direction is then north-east, which is also the direction of the Harmattan, which blows up to 2-3 km. Above $4 \mathrm{~km}$, we find the Subtropical Westerly Jet. The only difference between Bamako and Niamey is the intensity of the Harmattan in the middle of the day. In both locations, the LLJ disappears with the morning onset of turbulence and the wind weakens in Niamey in the low layers $\left(5-6 \mathrm{~ms}^{-1}\right)$ as described in Madougou et. al. [6].

An example of the characteristics of the lower troposphere is presented in Figure 5 and Figure 6 as height-time cross sections of horizontal wind, reflectivity and dissipation rate of turbulent kinetic energy, observed at Bamako from April $26^{\text {th }}$ to $29^{\text {th }}, 2005$ and at Niamey from May $3^{\text {rd }}$ to $6^{\text {th }}, 2006$. Figure $5 \mathrm{a}$ and $6 \mathrm{a}$ clearly show the LLJ. These periods correspond to the time when the ITD is located near Bamako and Niamey. It results in an alternation between the two wind regimes in the lower layers, the monsoon at night and the Harmattan during daytime, because the ITD moves southwards during the day and northwards during the night in connection with the diurnal cycle of the Saharan depression heat.

(a)
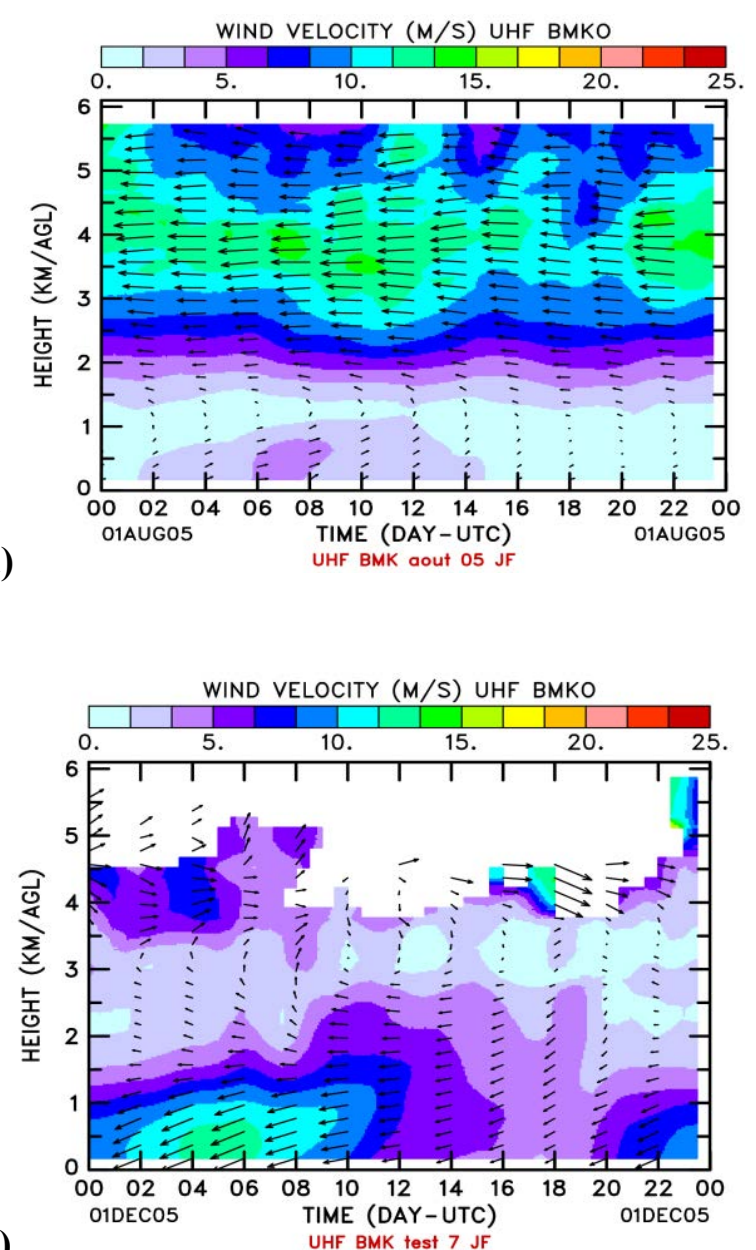
UHF BMK test $7 \mathrm{JF}$

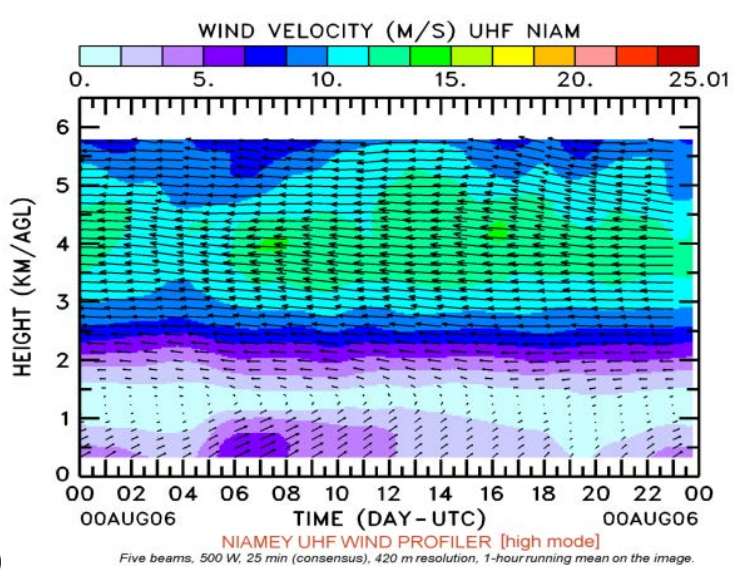

(b)

(c)

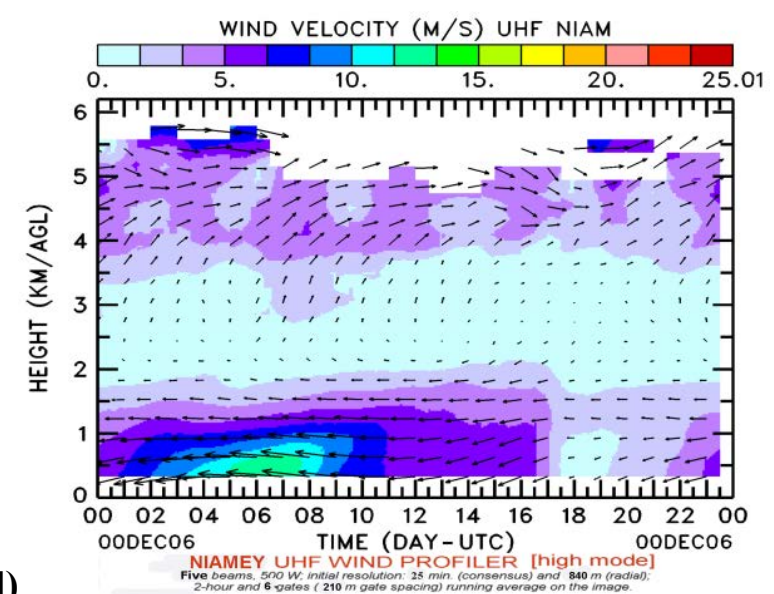

Figure 4 Composite days of the horizontal wind in August (a) at Bamako in 2005 and (b) at Niamey in 2006, and in December (c) at Bamako in 2005 and (d) at Niamey in 2006. The color scale shows the intensity of the wind speed

In the early morning, the jet can reach $10 \mathrm{~ms}^{-1}$ and its depth can grow to $1200 \mathrm{~m}$. This jet is roughly centered at 06H00 UTC and disappears shortly after 10H00 UTC. During this period, the monsoon blows from the south-west, advecting moisture at low levels and generating a high wind shear and a 
strong gradient of humidity at its top, above which the Harmattan blows. These shears and humidity gradients produce reflectivity maxima, which are well marked in Figures $5 \mathrm{~b}$ and $6 \mathrm{~b}$. In these figures, some reflectivity maxima appear in the night. Those correspond to the upper part of the jet. After sunrise, the thermal turbulence grows and gradually destroys the jet. The development of the atmospheric boundary layer (the top of the ABL is indicated by the maximum of the reflectivity, symbolized by black dots in the figures) starts slowly in the morning (before 10H00 UTC) and accelerates once the wind weakens. The top of the atmospheric boundary layer can reach 4-5 km (April $26^{\text {th }}$ at Bamako, May $4^{\text {th }}$ at Niamey). The development of the ABL also appears between $12 \mathrm{H} 00$ and $18 \mathrm{H} 00 \mathrm{UTC}$ in Figures $5 \mathrm{c}$ and $6 \mathrm{c}$, where the dissipation rate of turbulent energy is represented. On the other hand, the high nocturnal values of dissipation remain unexplained so far.
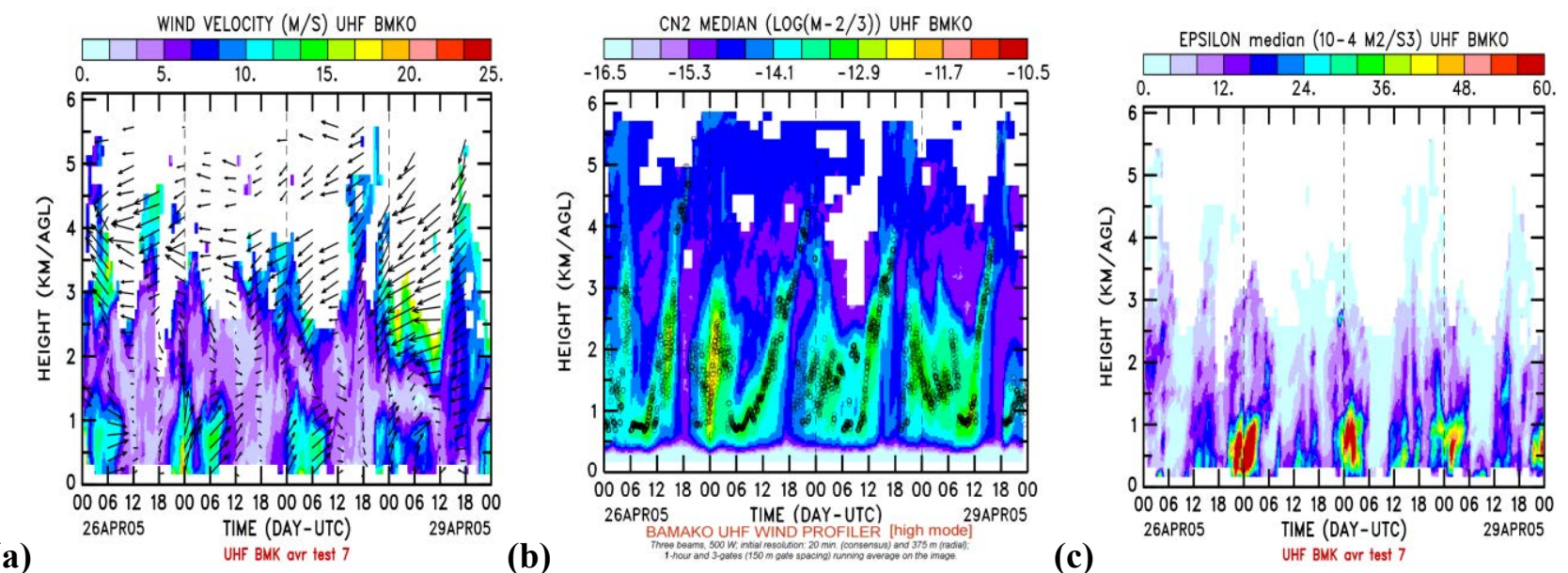

Figure 5 Height-time cross sections of (a) horizontal wind, (b) reflectivity and (c) dissipation rate of turbulent kinetic energy, obtained at Bamako from April $26^{\text {th }}$ to $29^{\text {th }}, 2005$. Black dots indicate the top of the inversion layer at night or the top of the $A B L$ during daytime
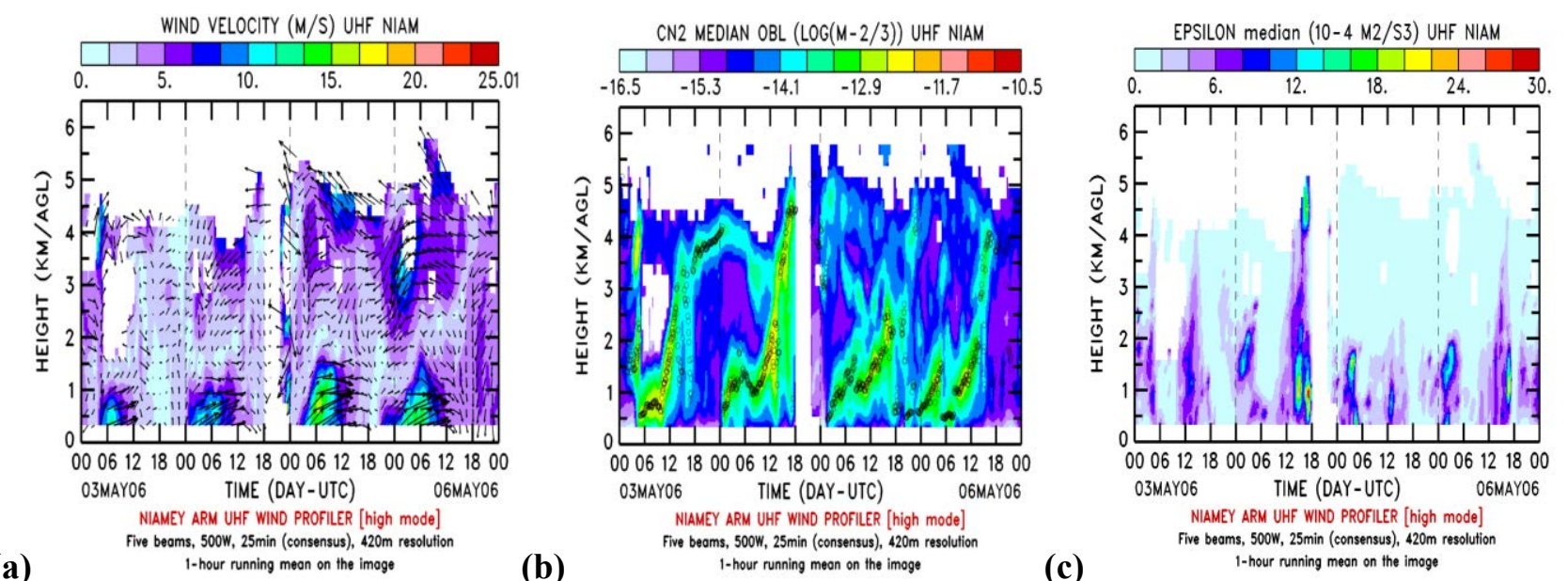

Figure 6 Height-time cross sections of (a) horizontal wind, (b) reflectivity and (c) dissipation rate of turbulent kinetic energy, obtained at Niamey from May $3^{\text {rd }}$ to $6^{\text {th }}, 2006$. Black dots indicate the top of the inversion layer at night or the top of the ABL during daytime

Wind Shear: The wind shear between two levels is the difference between the two horizontal wind vectors. It is thus defined both in magnitude and in direction:

$$
W S_{\text {mag }}=\left[\left(\frac{\partial u}{\partial z}\right)^{2}+\left(\frac{\partial v}{\partial z}\right)^{2}\right]^{1 / 2}
$$




$$
W S_{d i r}=\operatorname{arctg}\left\lfloor\frac{\left(\frac{\partial u}{\partial z}\right)}{\left(\frac{\partial v}{\partial z}\right)}\right\rfloor
$$

Wind shears are known to disturb air properties around airplanes by generating sudden disturbance of the relative wind speed or by producing turbulence. They therefore constitute major risks during take-off and landing [2]. They are known to have been directly or indirectly responsible for many aircraft disasters between 1964 and 1986 in some parts of the world and especially in the USA, where traffic is very heavy (see the statistics of aircraft accidents related to wind shear in the Federal Aviation Administration circular)[7].

Shears occurring near the ground can be due to low level jets, downbursts of thunderstorms or the presence of large obstacles on the ground (mountains, large buildings, etc.). In the Sahel lower troposphere, a vertical wind shear also appears between the monsoon layer and the Harmattan layer, as was seen (Figure 7) between $1000 \mathrm{~m}$ and $1500 \mathrm{~m}$ in August. This shear is not dangerous, because it is not too close to the surface and secondly, because the wind intensity is very low in this area. In contrast, the shear generated by the low level jet is far more dangerous.

Some studies [8] calculated the magnitude of the wind shear between 30 and $300 \mathrm{~m}$, from SODAR observations installed in the framework of AMMA on sites located about sixty kilometers east of Niamey. The first author is a forecaster at the National Meteorology Directorate of Niamey and he knows the standards of safety procedures for aircraft taking off or landing at an airport. In practice, an alert is triggered when the wind speed measured by the radiosonde at $600 \mathrm{~m}$ is above 30 knots $\left(15 \mathrm{~ms}^{-1}\right)$. Considering that the wind shear is maximum between 0 and $300 \mathrm{~m}$, from the observations they made between the beginning of June and mid-August, this threshold of $15 \mathrm{~ms}^{-1}$ corresponds to a wind shear of $5 \mathrm{~ms}^{-1}$ per $100 \mathrm{~m}$. Kaplan et. al. [9], who described a series of measurements made near Dallas airport in the Great Plains of the USA, indicates that the average shear is $2.9 \mathrm{~ms}^{-1}$ per $100 \mathrm{~m}$ at 200-300 m, i.e. below the maximum LLJ, located at $500 \mathrm{~m}$ on average.

Wind Shear Characteristics in the Sahel and its Consequences: Figure 7 shows the frequency distributions of wind shear magnitude and wind shear direction versus time, between 150 and $300 \mathrm{~m}$ at both sites, during the dry season and pre-monsoon period. The magnitude occurrences are spaced $2 \mathrm{~ms}^{-1}$ per $100 \mathrm{~m}$ and the direction occurrences $30^{\circ}$ per $100 \mathrm{~m}$.

In Niamey during the dry season, the period of strong shears is clearly linked to the LLJ since it occurs in a narrow time period around $06 \mathrm{H} 00$ UTC: $60 \%$ of the cases reach shears which require an alert to the pilots (higher than $4 \mathrm{~ms}^{-1}$ per $100 \mathrm{~m}$ ) (Figure 7 (b)). Such high shears can also be found at the same time in $20 \%$ of the occurrences in the $300-500$ m layer (not shown). These high shear values are within the Harmattan wind but, since the LLJ is stronger during this season, with a peak level closer to the surface, the shear magnitude is stronger. The majority of cases occur during the night with a wind shear direction between 90 and $150^{\circ}$ per $100 \mathrm{~m}$ (Figure 7 (d)), which is also dangerous for aircraft (cross-wind). In Bamako, high wind shears (higher than $4 \mathrm{~ms}^{-1}$ per $100 \mathrm{~m}$ ) represent only $16-22 \%$ of the cases and can occur at any time of the day (Figure 7 (a)). There are, however, $8 \%$ of the cases, the whole day long, when the wind shear can reach more than $6 \mathrm{~ms}^{-1}$ per $100 \mathrm{~m}$. Most of the wind shear directions are also between 0 and $90^{\circ}$ per $100 \mathrm{~m}$ (Figure 7 (c)) during the night. 
(a)

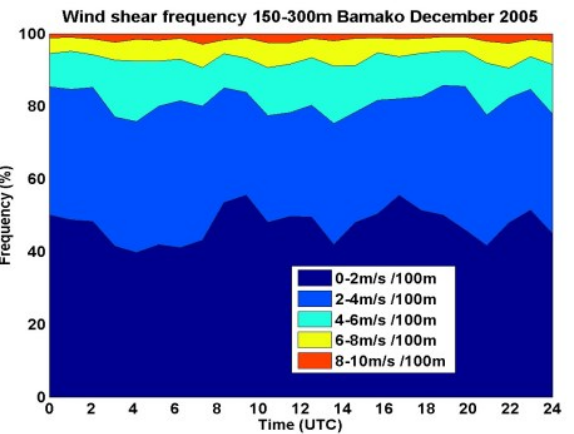

(c)
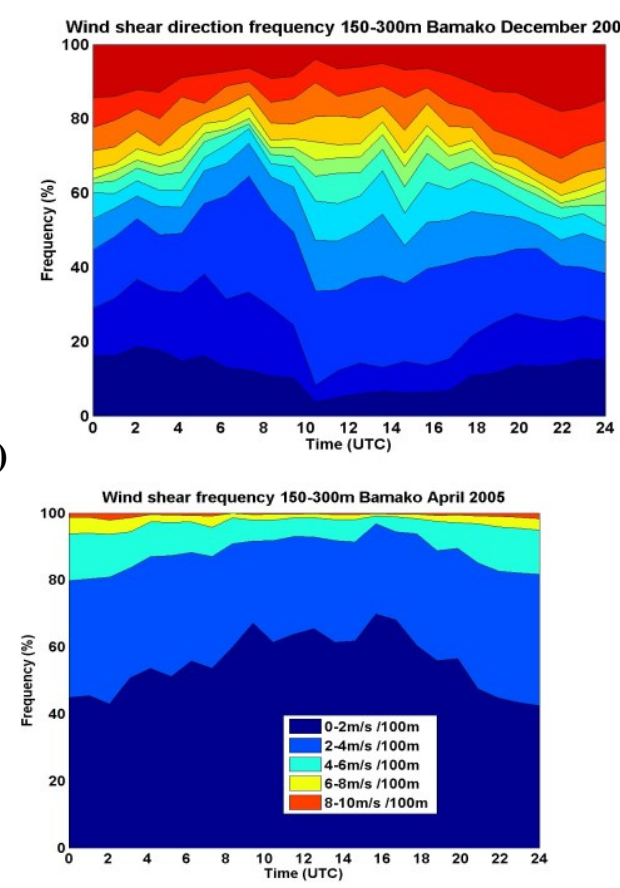

(e)

(g)

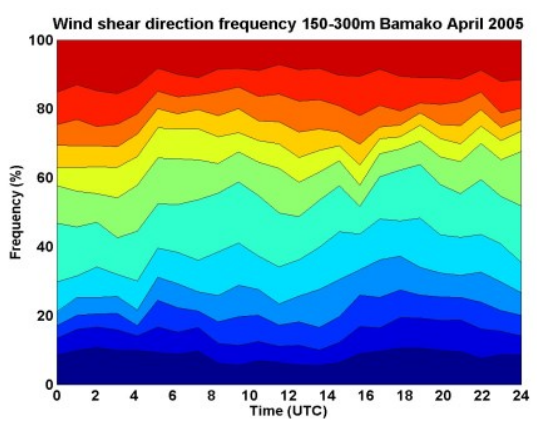

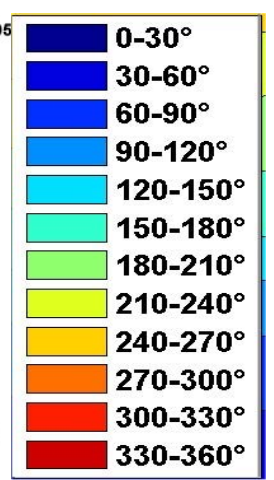

(d)

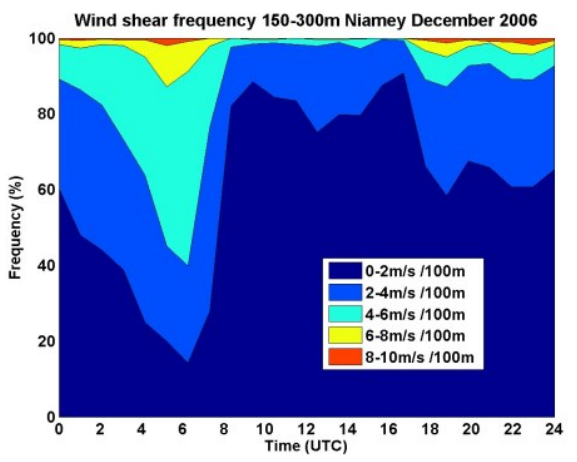

(b)
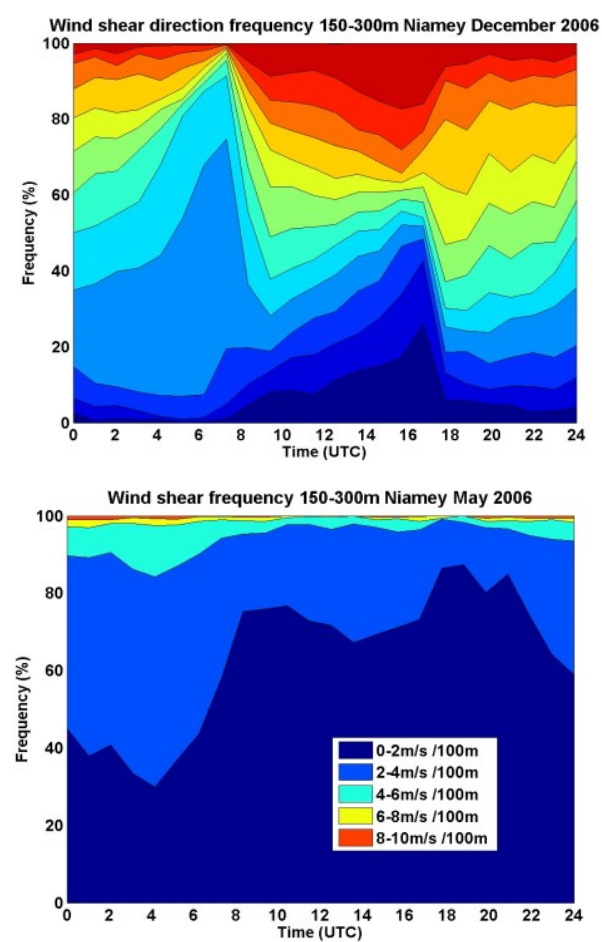

(f)
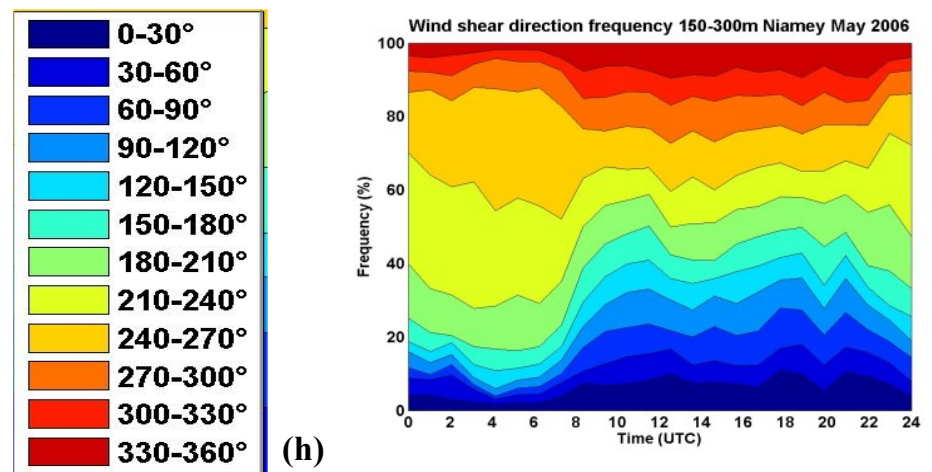

Figure 7 Frequency distributions of wind shear versus time: (a, b, e, f) in magnitude and (c, d, g, h) in direction observed in Bamako (left) or Niamey (right), during the dry or pre-monsoon periods

During the pre-monsoon period, high wind shears are not so frequent, either in Niamey or in Bamako (Figures 7 (e) and (f)). The highest shears occur mostly at night $(17 \%$ of the cases in Niamey and $20 \%$ in Bamako). In Bamako, the wind shear direction is almost equally distributed over the whole range of wind sectors (Figure $7(\mathrm{~g})$ ). In Niamey, 55\% of the night cases are in the $210-270^{\circ}$ sectors, which is also dangerous for aircraft (Figure $7(\mathrm{~h})$ ). The monsoon period (Figure 8 (a), (b), (c) and (d)) and post-monsoon period (not shown), revealed very rare high wind shears. 
Abdou et. al. [8] found higher wind shears in magnitude between 30 and $300 \mathrm{~m}$ during a period spanning May $31^{\text {st }}$ to August $17^{\text {th }}$ (i.e. from the pre-monsoon to the monsoon period) with 18 to $38 \%$ of wind shears greater than $4 \mathrm{~ms}^{-1}$ per $100 \mathrm{~m}$. The discrepancy between their results and ours probably stems from the fact that higher wind shears also occur between $30 \mathrm{~m}$ and $150 \mathrm{~m}$, in a range that cannot be reached by the UHF radar.

(a)
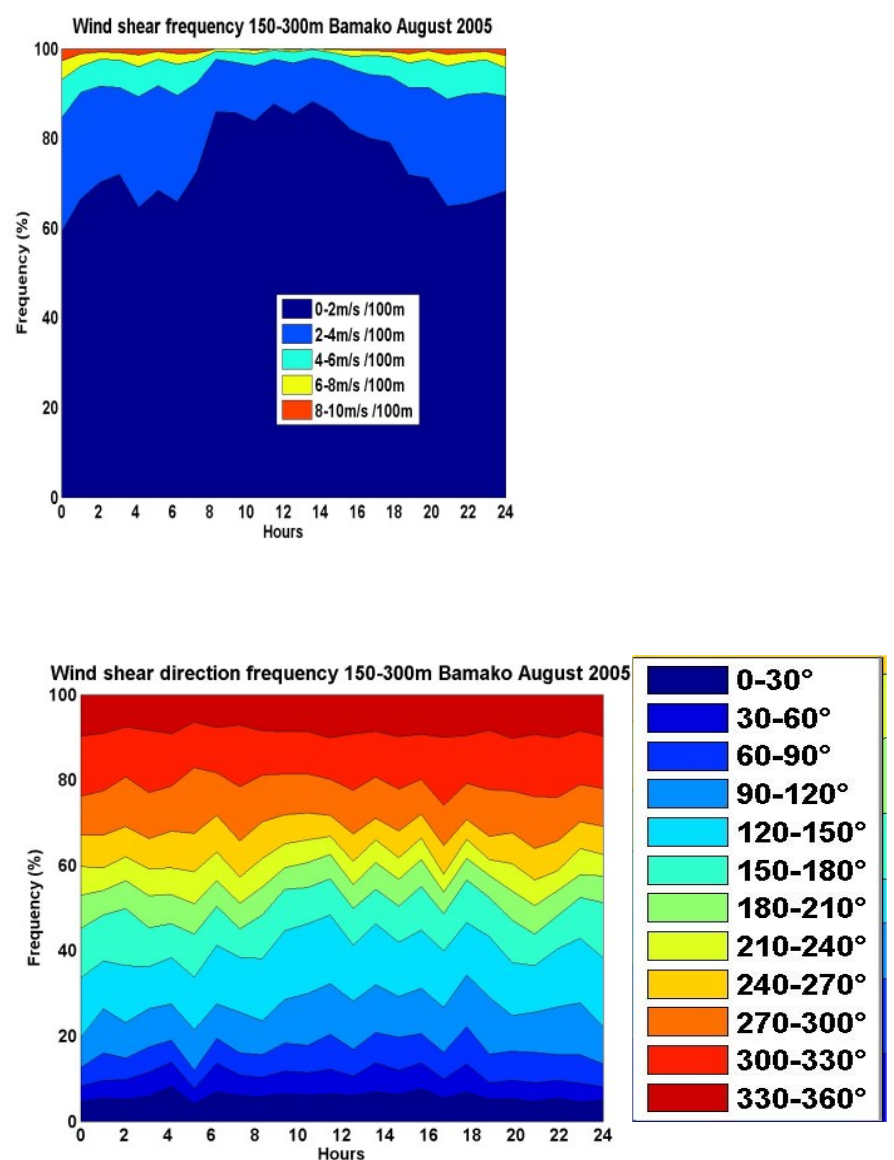

(b)
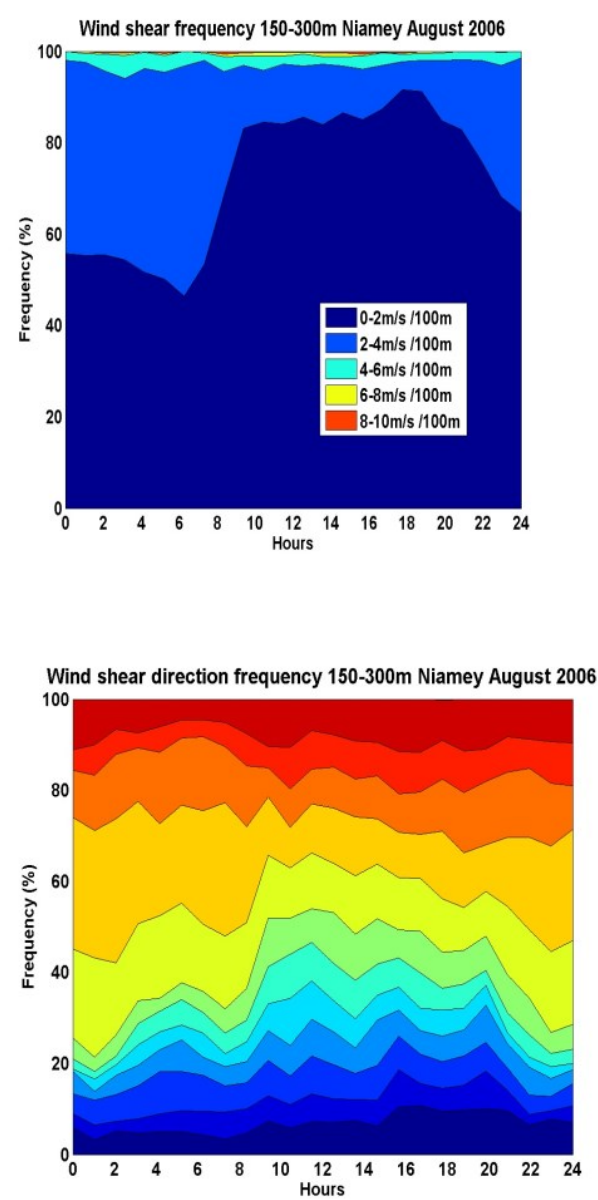

(d)

Figure 8 Frequency distributions of wind shear versus time: $(a, b)$ in magnitude and (c, d) in direction observed in Bamako (left) or Niamey (right), during the dry or pre-monsoon periods

\section{Conclusion}

This study shows that the strongest values of LLJ are encountered during winter, which corresponds to the dry season or during the transition period between the dry and the wet seasons. Associated with these strong values of LLJ, large wind shear, either in magnitude or direction, appear in the vicinity of the nocturnal jet. The probabilities of strong wind shear are most important between 150 and $270 \mathrm{~m}$. In the LLJ period, in Niamey it found $60 \%$ of cases of shear higher than $4 \mathrm{~ms}^{-1}$ per 100 $\mathrm{m}$ between 150 and $270 \mathrm{~m}$ and $20 \%$ between $270-500 \mathrm{~m}$. Shears higher than $4 \mathrm{~ms}^{-1}$ per $100 \mathrm{~m}$, appear in Bamako, where the pre-monsoon wind shear frequencies vary from 10 to $20 \%$ at $4-6 \mathrm{~ms}^{-1}$ per $100 \mathrm{~m}$, at the LLJ time $(21 \mathrm{H} 00$ to $06 \mathrm{H} 00)$. There are even cases, but less probable, where the wind shear can reach 6-8 $\mathrm{ms}^{-1}$ per $100 \mathrm{~m}$. In Niamey, the period to worry is between $03 \mathrm{H} 00$ and $06 \mathrm{H} 00$, which corresponds to the maximum of the LLJ. These shears of low layers are the most dangerous for aircraft. Both profilers were located in the airport area, which enabled accurate information to be provided to the pilots, who otherwise received conflicting measurement indications from their on-board instruments and the control tower. 


\section{Acknowledgments}

The authors of this work thank the University Abdou Moumouni (Niamey, Niger) and the INSUCNRS authorities. We would like to give special thanks to ASECNA for providing us the UHF profiler data in Bamako. We also thank the US Atmospheric Radiation Measurement program for operating the UHF wind profiler in Niamey and providing us the data.

\section{References}

[1] Madougou Saïdou; Saïd Frederique; Campistron Bernard; Lothon Marie; and Cheikh Fadel Kebe, Results of two eight-month, UHF radar observations of the nocturnal low-level jet for wind energy applications. Acta Geophysica. 60(5) (2012) 1413-1453, DOI: 10.2478/s11600-012-0062-4

[2] A.K. Blackadar, Boundary layer and maxima and their significance for the growth of nocturnal inversions. Bull. Amer. Meteor. Soc. 38 (1957) 283-290.

[3] J. Malcher and H. Kraus, Low-level jet phenomena described by an integrated dynamical PBL model. Bound.-Layer Meteor. 27 (1983) 327-343.

[4] Kalapureddy, M. C. R., M. Lothon, B. Campistron, F. Lohou, and F. Saïd, Wind profiler analysis of the African Easterly Jet in relation with the Boundary-layer and the Saharan Heat Low. Quart. J. Roy. Meteor. Soc. 136 (1) (2010) 77-91. DIO 10.1002/qj.494.

[5] Lothon, M., F. Saïd, F. Lohou and B. Campistron, Observation of the diurnal cycle in the low troposphere of West Africa. Mont. Wea. Rev., 136 (2008) 3477-3500.

[6] Madougou, S.; B. Campistron; F. Said; M. Lothon; F. Lohou and G. Canut Nine months of uhf wind profiler radar observation of low atmosphere at Bamako and Niamey. $2^{\text {nd }}$ International AMMA Conference, 26 - 30 November (2007), Karlsruhe (Germany).

[7] Federal Aviation Administration. Pilot wind shear guide: advisory circular $A C N^{\circ} 00-54$. US department of transportation (USA), (1988) 64 pp. Available online at

http: //rgl.faa.gov/Regulatory_and_Guidance_Library/rgAdvisoryCircular.nsf/list/AC\%2000-54/ \$FILE/AC00-54.pdf

[8] Abdou, K., D.J. Parker, B. Brooks, N. Kalthoff and T. Lebel, The diurnal cycle of lower boundary layer wind in the West African monsoon. Quart. J. Roy. Meteor. Soc. 136 (1) (2010) 6676. DIO 10.1002/qj.536.

[9] Kaplan, M.L., Y.L Lin., J.J. Charney, K.D. Pfeiffer, D.B. Ensley, D.S. DeCroix, R.P. Weglarz, A terminal area PBL prediction system at Dallas-Fort Worth and its application in simulating diurnal PBL jets. Bull. Am. Met. Soc. 81(2000) 2179-2204. 